\title{
Was Mattarella worth the trouble? Explaining the failure of the 2016 Italian constitutional referendum
}

\author{
FEDRA NEGRI* AND ELISA REBESSI \\ Department of Social and Political Sciences, Università degli Studi di Milano, Milano, Italy
}

\begin{abstract}
The election of President Mattarella is a turning point in Matteo Renzi's attempt to reform the constitution. This choice determined the loss of Forza Italia's support to the constitutional reform, thus leaving the Renzi cabinet and the Democratic Party alone on the Yes-side. Our goal is to assess the degree of Renzi's misjudgment by comparing two theoretical perspectives on voting behavior in direct-democratic settings through a nested design. Our results highlight that vote choices can be explained by both the systematic and the heuristic modes of information processing. Respondents' agreement with the content of the reform (systematic mode) and a positive evaluation of the Renzi cabinet (heuristic mode) are key predictors of Yes vote. Instead, the negative assessment of the economic situation is a crucial driver of No vote. Lastly, we build a bridge between these two perspectives by showing that partisan attachments conditioned the effect of respondents' content evaluation on voting behavior.
\end{abstract}

Keywords: Italy; referendum; voting behavior; prime minister; political parties

\section{Introduction}

On 4 December 2016 Italian citizens were called to vote on a wide-ranging constitutional reform in a confirmatory referendum. The reform bill entailed several constitutional modifications regarding the abolishment of perfect bicameralism, a significant reduction in the number of MPs in the Senate, the re-centralization of key regional policy competences, the abolishment of provinces, as well as the lowering of the quorum for abrogative referendums. Reform proponents maintained that it was designed to increase government stability and to slim the legislative process. Detractors argued that the reform would give too much power to the prime minister (PM), thus harming the role of the Parliament (De Angelis et al., 2017).

However, policy arguments on the prospective equilibrium among the powers of the state did not prevail in the public debate concerning the 2016 Italian constitutional referendum. In fact, PM Matteo Renzi referred to this constitutional reform as the most important piece of legislation in the entire legislature. Moreover, he initially promised to step down in case of rejection, the survival of his government depending on a positive referendum outcome.

* E-mail: fedra.negri@unimi.it 
This strong personalization of the referendum campaign pushed the alignment of political parties along a sharp government/opposition line. The majority of the Democratic Party's (PD) frontbenchers ${ }^{1}$ (Fasano et al., 2017) and their smaller coalition partner New Center Right (NCD) supported the reform, whereas all the opposition parties stood by the No-side because they saw a promising opportunity to get rid of their political adversary Renzi. Among opposition parties, the strategic behavior of the center-right party Forza Italia (Go Italy - FI) deserves mention. In fact, FI leader Silvio Berlusconi withdrew his endorsement to the constitutional reform after the almost unilateral election of Sergio Mattarella as President of the Italian Republic at the hands of the PD. With the provocative title of this paper, 'Was the election of President Mattarella worth the trouble?,' we argue that PM Renzi openly renounced the political support of FI to the constitutional reform in order to obtain the election of President Mattarella.

We maintain that the 2016 Italian constitutional referendum is an interesting case to investigate citizens' decision-making processes in direct-democratic settings. In fact, from a policy point of view, the constitutional reform was a highly complex package of funding provisions, whose consequences on policymaking and the state of the economy might have appeared uncertain to citizens. From a political point of view, the reform was immediately tied to the survival of the Renzi cabinet, a fact that increased its salience in the eyes of citizens. The Renzi cabinet openly bet everything on a positive referendum outcome, political parties took clear-cut positions and Italian media hosted several and intensive debates on the topic, making information widely and easily available.

These conditions make the 2016 constitutional referendum a good setting to investigate a key question: when citizens take part in a referendum, do they vote according to their evaluations on the policy at stake or do they cast their ballots according to peripheral dynamics and heuristics? This paper builds on the existing literature on voting behavior in direct-democratic settings by comparing the role played by the so-called 'systematic' and 'heuristic' modes of information processing (e.g. Lodge and Taber, 2013; Taber and Young, 2013) in the Italian case. To clarify, the systematic form of decision-making maintains that voters collect information accurately and examine policy arguments critically in order to decide how to cast their ballots. The 'heuristic' mode, on the other hand, argues that under low information and in presence of conflicting views on the object of vote, citizens act rationally and employ heuristics, such as parties' positions (Hobolt, 2006; Borges and Clarke, 2008), and cognitive shortcuts, such as trust in government (Kriesi, 2005; Clarke et al., 2013) and evaluations of the state of the economy (Hobolt, 2016), to ground their vote choices.

\footnotetext{
1 The PD was internally split into minority leftist factions opposing the reform and the mainstream faction supporting the reform (e.g. Sentimeter, 2015; Fasano et al., 2017). This intra-party heterogeneity led to a party fission in February 2017.
} 
We compare these two approaches by using a nested logit model (McFadden, 1978; Born, 1990; Thurner and Eymann, 2000) on the data provided by the ITANES Referendum Questionnaire (2016). ${ }^{2}$ In fact, this technique allows us to model vote choice as a sequential process, namely by considering that at any given point in time only a subset of the alternative is actually available (Steenbergen, 2008: 162).

The results highlight that voting behavior at the 2016 constitutional referendum can be explained by both respondents' evaluation of the content of the reform (systematic mode) and by cognitive shortcuts (heuristic mode). In detail, respondents' agreement with the content of the reform (systematic mode) and a positive evaluation of the Renzi cabinet (heuristic mode) are key predictors of Yes vote. However, they are unable to explain the choice of voting No. Instead, the heuristics related to the assessment of the economic situation and partisan attachments played key roles. The worse the respondent's assessment of the economic situation is, the more he/she is likely to vote No. Lastly, the more the respondent is ready to vote for FI or the Five Star Movement (M5S), the more he/she is likely to reject the constitutional reform. These partisan attachments are so strong that they could even condition the positive effect of content evaluation on the probability to vote Yes. The article is structured as follows. The next section motivates the focus on the 2016 constitutional referendum by providing key information on Italian politics. Then, we review the literature on voting behavior in direct-democratic settings and formulate our research hypotheses. Last, we describe the data set and the model specification. The analytical section displays the results.

\section{The political context around the 2016 Italian constitutional referendum}

The use of a referendum for constitutional amendments, either as an absolute requirement or as an optional alternative, is common to several countries (Lijphart, 2012). Referendums are usually prescribed in addition to legislative approval by simple or qualified majority, making constitutional amendments harder to adopt (Gallagher, 1995).

Italy is an interesting case as the use of referendum represents an 'alternative method' to approve a constitutional reform without the qualified majority in Parliament. In fact, a constitutional reform approved by legislators with the mere simple majority can only be adopted if it obtains the support of the majority of Italian voters in a popular referendum without quorum (see art. 138 Cost.). Thus, former PM Renzi had two alternative paths: either reaching the qualified majority in Parliament with the key support of the center-right party FI or approving the reform with the simple majority, thus betting on his ability to mobilize the electorate in the confirmatory referendum.

Of course, each path implies different strategies. Reaching the qualified majority in both Chambers requires reform proponents to find a large parliamentary

\footnotetext{
2 Available at: http://www.itanes.org/questionari-itanes/
} 
support. We call this strategy 'consensual strategy.' Reaching the simple majority plus winning a referendum asks instead reform proponents to bet on the support of the majority of voters. We call this strategy 'popular vote strategy.'

But what makes one of the two strategies more likely to succeed? If we look back to the history of constitutional reforms in Italy, consensual strategies seem to have been more successful. In fact, major attempts to reform the Italian constitution (i.e. the Bozzi Bicameral Committee in 1983-1985, the De Mita-Iotti Bicameral Committee in 1992-1994, and the D'Alema Bicameral Committee in 1997) got sunk in Parliament under the conflicts between government and opposition parties (Ferrera and Gualmini, 2004). In its attempt to reform the constitution in 2006, the center-right coalition led by FI leader Berlusconi decided to rely on the strength of its parliamentary majority only (Bull and Newell, 2009). Thus, the subsequent confirmatory referendum saw the unanimous mobilization of center-left parties and the constitutional reform was rejected in popular vote. On the contrary, opposition parties were much more divided in the 2001 constitutional reform, which was proposed by the center-left coalition and was finally adopted through a popular referendum (Keating and Wilson, 2010). ${ }^{3}$

According to Tsebelis $(2002,2017)$, it is impossible to establish a priori which strategy (i.e. consensual strategy vs. popular vote strategy) is more likely to succeed in changing the status quo (i.e. in reforming the constitution) because the constitutional core (i.e. the set of provisions that can never be changed) depends on the actual preferences of the actors involved. The key difference between the two strategies is that the popular vote introduces an additional veto player, that is to say the population, with its own preferences.

With regards to the 2016 constitutional referendum, Tsebelis claimed that the popular vote strategy chosen by Renzi was more likely to succeed than the consensual strategy because Italian voters were more prone to reduce the power of the Senate (and the numbers of MPs) rather than the Senators' (Tsebelis, 2017: 8).

However, Tsebelis's argument requires citizens to manifest clear preferences on the content of the constitutional reform and to take part in a referendum to express their sincere opinions (systematic mode). Vice versa, referendums are often described in the literature as 'second order elections,' where citizens simply take the chance to express their judgments on contextual elements (e.g. Reif and Schmitt, 1980), such as the economic situation, the performance of the incumbent government and the political élites (heuristic mode).

The election of Mattarella as President of the Republic in January 2015 without the agreement of FI is a turning point in the history of the 2016 constitutional

\footnotetext{
${ }^{3}$ In that case, the main opposition parties (amongst them FI, National Alliance-AN, and the Northern League-NL) did not vote openly against the reform, but chose not to participate to the parliamentary vote. Then, the reform gained the open support of prominent members of FI (as the governor of Lombardy Region, Roberto Formigoni, and the governor of Puglia Region, Raffaele Fitto) in the subsequent confirmatory referendum. Moreover, LN leader Umberto Bossi openly put pressure on his party voters to abstain, rather than voting No, in the referendum.
} 
referendum. Essentially, Renzi broke the political agreement he had signed 1 year before with FI leader Berlusconi, ${ }^{4}$ thus abruptly dismissing the consensual strategy in favor of the popular vote strategy. More interestingly, by breaking up with Berlusconi, Renzi decided to give up FI's support in the subsequent confirmatory referendum: he chose to undertake the referendum on his own, with the support of his cabinet and his party (i.e. the PD) only.

The infringement of this pact in order to elect President Mattarella has been labeled by the large majority of Italian media as 'Renzi's political masterpiece' (e.g. La Stampa, Il Corriere della Sera, Il Foglio, and Huffington Post). Almost 3 years later, after losing the referendum and, consequently, the premiership, a simple question comes to mind: was the election of President Mattarella worth the trouble? In retrospect, it is rather easy to provide a negative answer. However, in the winter of 2015 Renzi chose to place a bet on his popularity, the positive evaluation of his cabinet, and the strength of his party. Was this choice what Homer would have called an act of hybris? To assess the degree of Renzi's misjudgment, we need to understand which cognitive mechanisms drove the vote choices of citizens at the 2016 constitutional referendum.

\section{Systematic vs. heuristic reasoning in referendums: literature review and hypotheses}

On 4 December 2016, Italian citizens casted their ballots on a far-reaching constitutional reform in a referendum vote without quorum. Ideally, their voting behavior should have been based on an informed judgement on the policy content of the issue at stake (e.g. Lupia and Matsusaka, 2004; Kriesi, 2005; Hobolt, 2007). That is to say, they were meant to be collecting accurate information, critically evaluate the pros and cons and, finally, come to an informed vote choice.

According to recent studies, this systematic mode of information processing is not as uncommon as one might think. In fact, voters are increasingly aware of the main policy arguments of the campaign (Colombo, 2016) and they often rely on policy arguments to make their vote choices, when and if these argument are available (Boudreau and MacKenzie, 2014; Colombo and Kriesi, 2016). Thus, we formulate our first hypothesis:

HYPOTHESIS 1: The more voters agree with the policy content of the constitutional reform, the more (less) they are likely to vote Yes (No) at the referendum.

However, since the average level of interest in politics and political knowledge tend to be rather low, individuals are not naturally inclined to invest their time in

${ }^{4}$ This agreement, known as the 'Nazareno Pact,' was signed by Renzi and Berlusconi on 18 January 2014. Even if its content was kept private, the agreement widely concerned the reform of the electoral law and of the constitution. 
collecting 'encyclopedic' political information (Lupia, 1994). The so-called dual process models of reasoning state that individuals follow the least-effort principle, that is they aim at reaching a vote choice that reflects their policy preferences as best as possible by minimizing informational and cognitive efforts (e.g. Kahneman, 2011). Besides, the 2016 constitutional reform included a package of such complex funding provisions that even the most informed and motivated individuals could not fully grasp its overall consequences. In such circumstances, individuals may resort to peripheral considerations and cognitive shortcuts as substitutes for policy considerations to reach a reasonable vote choice (e.g. Lupia and McCubbins, 1998: 2). This decisionmaking strategy is labeled 'heuristic mode of information processing' (Lupia et al., 2000; Kriesi, 2005).

Since Fiorina (1981), scholars have underlined the key role played by the economic situation in shaping voting behavior. In a nutshell, if the economy is doing well, citizens are more likely to vote for governing parties, while if the economy is going poorly, citizens tend to punish incumbents (e.g. Lewis-Beck and Stegmaier, 2007). This mechanism also works in the stance of referendums: citizens may punish (reward) governing parties for their performance in the economic sphere by rejecting (accepting) their reform proposal. For example, the economic conditions experienced by British people were key drivers of the vote in the 2016 Brexit referendums (Hobolt, 2016). We argue that this mechanism may have played a role in our case study as well. To emphasize this simplification of voters' reasoning, we could assert that if the government has managed the economy badly (well), the constitutional reform which was formulated and supported by the same government will also be likely to be badly (well) written. Thus, we formulate our second hypothesis:

HYPOTHESIS 2: The worse the voters' retrospective evaluation of the economic situation, the less (more) they are likely to vote Yes (No) at the referendum.

Similarly, voters' behavior in referendums may be affected by their assessments of the overall performance of the cabinet: ceteris paribus, a reform supported by a popular cabinet is more likely to be approved (Gallagher, 2015: 282). Of course, citizens' degree of approval towards the cabinet may be driven by both policy and valence issues (Stokes, 1963). For example, it is claimed that President Mitterand's unpopularity nearly caused the defeat of the Maastricht Treaty referendum in France in 1992, while the personal popularity of the PM Gonzalez ensured that the Spanish cast their vote to stay in the NATO in 1986 (LeDuc, 2003). Accordingly, we formulate our third hypothesis:

HYPOTHESIS 3: The better voters evaluate the incumbent government, the more (less) they are likely to vote $\mathrm{Yes}(\mathrm{No})$ at the referendum.

This mechanism is likely to have played a leading role in our case study. PM Renzi linked the fate of his government to the approval of the constitutional reform from the very beginning, thus transforming the referendum into a verdict on his 
personality. A survey experiment hints that this strategy may have been counterproductive: indeed, voters' support for the reform weakens when it is explicitly linked to the government (Colombo et al., 2016).

Moreover, when confronted with complex policy decisions, citizens may rely on signals from trusted political parties, partisan attachments and feelings (e.g. Slothuus and de Vreese, 2010). Indeed, citizens are in lack of time, interest and cognitive capacity to evaluate the possible consequences of accepting or rejecting a referendum proposal (Borges and Clarke, 2008: 437; Clarke et al., 2004: 346). Thus, following party recommendations can be an important heuristic helping citizens to determine what information is trustworthy (Hobolt, 2009: 35-7; Lupia and McCubbins, 1998). However, empirical evidences on partisan effects are not clear-cut (e.g. de Vreese, 2006; Neijens and van Praag, 2006).

Since the majority of the PD frontbenchers campaigned for the Yes-side (together with the small NCD party), while all the other parties (i.e. FI, M5S, and Northern League - LN) stood by the No-side, we expect that:

HYPOTHESIS 4A: The closer voters are to the PD, the more (less) they are likely to vote Yes (No) at the referendum.

HYPOTHESIS 4B: The closer voters are to FI, the less (more) they are likely to vote Yes (No) at the referendum.

HYPOTHESIS 4C: The closer voters are to the M5S, the less (more) they are likely to vote Yes (No) at the referendum.

HYPOTHESIS 4D: The closer voters are to LN, the less (more) they are likely to vote Yes (No) at the referendum.

The hypotheses listed so far will guide us in the learning of whether Italian voters in the 2016 constitutional referendum were driven mainly by substantive information about the content of the constitutional reform (Hypothesis 1) or whether peripheral dynamics (i.e. retrospective economic evaluation, the popularity of the Renzi cabinet and partisan attachments) prevailed (Hypotheses 2-4). Identifying the main drivers of voters' choices in direct-democratic settings is crucial as they affect the quality of democratic decisions indeed.

However, this paper takes a step forward in order to understand whether peripheral dynamics also have a conditioning effect on the impact of substantive policy considerations on voting behavior. Was a negative evaluation of the economy (heuristic mode) able to nullify the effect of a positive evaluation of the complex provisions embedded in the constitutional reform (systematic mode)? Else, did a positive evaluation of the Renzi cabinet contain the effect of a skeptical content evaluation (systematic mode)? Finally, did Italian voters conform too readily to the views of their trusted parties (heuristic mode) even at the cost of neglecting their opinions on the issue at stake (systematic mode)? The empirical analysis described in the next section will help us test the hypotheses and answer these additional questions. 


\section{Research design}

\section{Data and operationalization}

The empirical analysis is based on the 2016 ITANES Referendum Questionnaire. This survey is performed on a representative sample of Italian citizens. Each respondent was interviewed both before and after the 2016 constitutional referendum. When available, independent variables are built from data collected before the election day to rule out endogeneity concerns (see Appendix Table A1 for details).

The empirical analysis employs a nested logit model to operationalize respondent's choice as a sequential process (McFadden, 1978; see the next section for details in the model specification). A data set suitable for standard discrete choice models provides one observation for each individual. On the opposite, a data set suitable for the nested model specification shows one observation for each alternative within each individual and a multi-categorical dependent variable to indicate whether the alternative is chosen or not (0-1). On 4 December, each respondent had three alternatives: abstention, No vote, and Yes vote. ${ }^{5}$ Thus, we shaped the original data set so that it shows all three observations for each respondent. Then, we built the multi-categorical dependent variable Voting Behavior to code respondent's choice probabilities to take part in the 2016 constitutional referendum and to express an eligible vote. If a respondent did not take part in the 2016 referendum, Voting Behavior is equal to 1 for the alternative abstention, 0 otherwise. If a respondent took part in the 2016 referendum and voted No (Yes), Voting Behavior is equal to 1 for the alternative No (Yes) vote, 0 otherwise.

Hypothesis 1 maintains that voters took their final decisions in the 2016 constitutional referendum according to a systematic mode of information processing. We test this claim through an additive index labeled Content Evaluation. It is given by respondent's judgment on the overall reform and on five specific topics (i.e. the abolishment of provinces, the abolishment of perfectly symmetric bicameralism, the re-centralization of energy and infrastructure domains, the lowering of the quorum for abrogative referendums and the reduction of MPs in the Senate). This index ranges from 0 (very negative evaluation) to 10 (very positive evaluation).

Besides, Hypotheses 2-4 argue that three heuristics affected voting behavior: namely, respondent's negative evaluation of the economy, respondent's positive evaluation of the Renzi cabinet and respondent's political attachments.

The ordinal variable Evaluation Economy captures respondent's opinion on the state of the national economy over the last year. It ranges from 0 (very positive evaluation) to 10 (very negative evaluation).

Similarly, the ordinal variable Evaluation Renzi Cabinet measures respondent's opinion on the overall performance of the Renzi cabinet. It ranges from 0 (very negative evaluation) to 10 (very positive evaluation).

\footnotetext{
5 Blank ballot is omitted due to small sample size.
} 
As for partisan attachments, we use respondent's propensity to vote for the four largest Italian parties (i.e. PD, M5S, FI, and LN) on a 0-10 scale. Unfortunately, this item is only available in the post-referendum wave, thus we cannot rule out endogeneity concerns completely. However, the party displaying the highest propensity to be voted usually coincides with the party (or the coalition of parties) chosen by the respondent at the 2014 European Parliament Elections. ${ }^{6}$ Therefore, the internal validity of this measure appears to be confirmed (this strategy has been followed by Camatarri and Segatti, 2017 too).

Lastly, since the effort people are willing to put into an informed vote choice depends on their motivation and ability (De Angelis et al., 2017), we were prompted to assess respondent's political involvement and level of education.

The additive index Political Involvement takes into account respondent's propensity to discuss politics with relatives, friends, and colleagues, to gather information on Italian politics and the constitutional reform from both media and new media, and their direct involvement in the electoral campaign.

The ordinal variable Education is equal to 1 if respondents have no educational degree or an elementary degree; 2 if they earned a junior high school degree; 3 if they finished high school and 4 if they have a university degree or higher.

Labor market status, age cohorts and gender are controlled for. Appendix Tables A1 and A2 provide descriptions and summary statistics. ${ }^{7}$

\section{Model specification}

We test the listed hypotheses through a nested logit model. It is a probabilistic choice model formulated by the Nobel Prize McFadden (1978) to operationalize choice as a sequential process. Decision makers are assumed to be utility maximizers that evaluate the alternatives in consecutive steps. Therefore, the model is especially suitable for modeling decision-making processes in which, from a certain time on, only a subset of alternatives is still available. ${ }^{8}$

Probabilistic choice models maintain that utility contains two systematic components and one random component. Systematic components include the attributes of the decision maker and those of the alternatives. The random component consists of unobserved attributes of the alternative, unobserved attributes of the decision maker, measurement error, and proxies or instrumental variables (Manski, 1977). Due to the random component, utility maximization and consequently choice are probabilistic.

Usually, probabilistic choice models (e.g. Lucean-type models; Luce, 1959) make rather stringent assumptions about the random component of the utility. In fact, they assume that the property of independence of irrelevant alternatives (IIA) is

\footnotetext{
${ }^{6}$ Note that we cannot employ respondents' vote choices in the 2014 EU elections because there is scarce data. Moreover, we need a continuous variable for the nested-logit model (see the sub-section Model Specification).

7 The wording of the ITANES's variables can be found at: http://www.itanes.org/questionari-itanes/

8 This section is based on the following sources: Born (1990), Train (2007), Thurner and Eymann (2000), and Steenbergen (2008).
} 


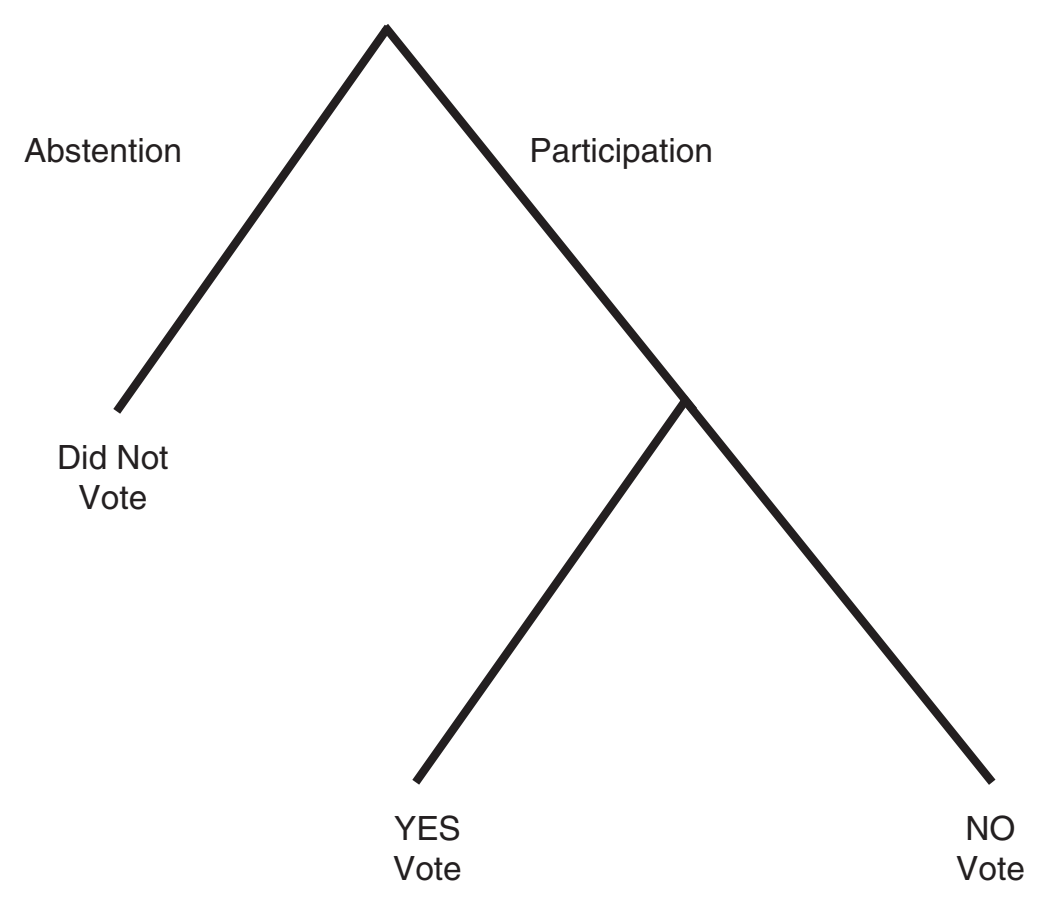

Figure 1 Decision tree.

fulfilled, meaning that the random component of the utility should be identically distributed, independent, and homoscedastic. Instead, the nested logit model relaxes this assumption.

In a nested logit model, the researcher establishes the nesting structure, namely how many groups (nests) are included and which alternatives belong to which nest. Each nest should feature a subset of more similar options.

Our decision tree groups the alternatives in two nests (abstention) and (Yes vote, No vote). ${ }^{9}$ We maintain that the property of belonging to the same nest is due to temporal considerations: the will to cast one's vote precedes the decision of voting Yes or No. Indeed, since the constitutional referendum did not request the quorum, abstention cannot be seen as a strategic choice. Only if respondents participate voting Yes or No becomes relevant.

There are three alternatives in the structure of Figure 1: $1=$ abstention; $2=$ Yes vote, $3=$ No vote. Let $\mathrm{Y}_{q}=1,2,3$ be the observed choice for decision maker $q$.

Under a utility maximization assumption, $\mathrm{Y}_{q}=i$ if $\mathrm{U}_{q i}>\mathrm{U}_{q j} \forall j \neq \mathrm{i}$. For instance, $\mathrm{Y}_{q}=2$ if $\mathrm{U}_{q_{2}}>\mathrm{U}_{q_{3}}$ and $\mathrm{U}_{q_{2}}>\mathrm{U}_{q_{1}}$. We assume that for decision maker $q$, the utility of alternative $i$ is conceptualized as random, consisting of a systematic component $\left(\mathrm{V}_{q_{i}}\right)$ and a random component $\left(\varepsilon_{q}\right)$ :

$$
\mathrm{U}_{q i}=\mathrm{V}_{q i}+\varepsilon_{q i}
$$

$\mathrm{V}_{q i}$ is a function of explanatory variables and parameters to be estimated and $\varepsilon_{q i}$ a random error term that captures the unobserved attributes of the utility. If

9 Blank ballot is omitted due to small sample size. 
explanatory variables involve characteristics of the individual making the choice, the variable assumes the form of the individual characteristics interacted with alternative-specific dummy variables (Born, 1990).

The nested logit model assumes that the errors of similar alternatives are correlated, while the errors of dissimilar alternatives are constrained at 0 . Since alternatives 2 and 3 are similar, and indeed they are grouped in the same nest, then $\varepsilon_{q_{2}}$ and $\varepsilon_{q_{3}}$ are correlated. Instead, alternatives 1 and 2 are dissimilar, therefore $\varepsilon_{q_{1}}$ and $\varepsilon_{q_{2}}$ are uncorrelated.

In addition, error terms are assumed to follow a Gumbel's Type B extreme value distribution (Born, 1990). Resulting choice probabilities are of the following type:

$$
\pi_{1}=\frac{\exp \left(V_{1}\right)}{\exp \left(V_{1}\right)+\left(\sum_{j=2}^{3}\left(\exp \left(V_{j} / \lambda_{2}\right)\right)^{\lambda_{2}}\right.}
$$

and

$$
\pi_{2} / \pi_{3}=\frac{\exp \left(V_{2} / \lambda_{2}\right)}{\exp \left(V_{3} / \lambda_{2}\right)}
$$

The $\pi_{1}$ equation represents the marginal probability of abstaining rather than voting for any option.

The $\pi_{2} / \pi_{3}$ equation represents individual conditional probability of voting Yes, given that he/she chose to participate to the referendum. The relative choice probabilities between alternatives 2 and 3 are entirely given by the utilities of those alternatives. No other alternative influences the likelihood of voting Yes or No. This would be true even adding other alternatives to the nest. In other words, for any two alternatives in the same nest, the ratio of probabilities is independent from the existence of other alternatives in the same nest: the IIA assumption holds within each nest. Conversely, for any two alternatives in different nests, the IIA assumption does not hold.

$\lambda$ is a measure of the degree of independence in unobserved utility among the alternatives in a choice subset and it is called 'dissimilarity parameter'. In $\pi_{2} / \pi_{3}$ equation, $\lambda_{2}$ is the dissimilarity parameter for the choices in the second nest (Yes vote, No vote). A high $\lambda$ means greater independence and less correlation. A value of $\lambda$ of 1 means complete independence in the nest. If $\lambda$ is equal to 1 for all nests, the nested logit would collapse into the standard logit model. In our case study, a value of $\lambda$ of 1 for all nests would mean that the options Yes voting and No voting are interchangeable with the choice of abstaining. Conversely, a value of $\lambda$ of 0 would entail suggest the presence of separate decisions on whether and what to vote for. Testing the distance of $\lambda$ from 0 determines the appropriateness of the choice of a nested logit model.

\section{Results}

Table 1 displays the nested logit predictors for the 2016 constitutional referendum vote choice. 
Table 1. Vote choice in the 2016 Italian constitutional referendum - nested logit model

\begin{tabular}{lccc}
\hline \hline & Abstention & Yes & No \\
\hline Vote choice (Yes/No) & & & \\
$\quad$ Content evaluation & - & $0.387(0.066)^{* * *}$ & $-0.055(0.046)$ \\
Evaluation economy & - & $-0.308(0.076)^{* * *}$ & $0.121(0.055)^{* *}$ \\
Evaluation Renzi cabinet & - & $0.149(0.057)^{* *}$ & $-0.0629(0.048)$ \\
PTV Democratic Party & - & $0.095(0.045)^{* *}$ & $-0.162(0.042)^{* * *}$ \\
PTV Forza Italia & - & $-0.080(0.048)^{* *}$ & $0.107(0.039)^{* * * *}$ \\
PTV Five Star Movement & - & $-0.170(0.048)^{* * *}$ & $0.162(0.032)^{* * *}$ \\
PTV Northern League & - & $-0.060(0.044)$ & $0.054(0.033)$ \\
Abstention/participation & & & - \\
Political involvement & $-0.949(0.092)^{* * *}$ & - & - \\
Education & $0.009(0.119)$ & - & - \\
Labor market status: blue collar & $0.619(0.319)^{*}$ & - & - \\
Age cohorts & $-0.185(0.124)$ & - & - \\
Female & $-0.099(0.156)$ & - & 2673 \\
$N$ & 2673 & 2673 & \\
\hline \hline
\end{tabular}

RUM-consistent nested logistic regression. Maximum-likelihood estimated nested logit coefficients. Likelihood $=-1731.0758$. Likelihood ratio test for independence of irrelevant alternatives: $P=0.029$. Base outcome for abstention/participation: Participation. The categories of Labor Market Status are included, but not reported, for purpose of readability (reference category: 'employee, executive, professor, and teacher'). Robust SE in parentheses. $* * P<0.01, * * P<0.05, * P<0.1$.

First, we verify whether it is possible to validate the hypothesized nested structure. The nested logit specification is appropriate if $0<\lambda<1$. In our case, the likelihood ratio test rejects the null hypothesis that all the dissimilarity parameter coefficients have value 1 at the $95 \%$ level $(\mathrm{P}=0.029)$.

Then the results may be interpreted beginning with the bottom-level alternatives: Yes vote and No vote. The outcome of the estimation process displays choice probabilities and not choices per se (Hensher et al., 2005: 326).

The evaluation of the content of the constitutional reform is a crucial determinant of voting behavior. The estimates suggest that the more a respondent agrees with the content of the reform, the more he/she is likely to vote Yes. This finding is consistent with Hypothesis 1 and confirms that the systematic mode of information processing plays an important role. However, the effect of the predictor Content Evaluation does not reach statistical significance on the probability of voting No, suggesting that the mechanisms behind Yes vote and No vote do not match. Indeed, respondents that voted No on 4 December 2016 did not seem to be driven by a systematic mode of information processing.

According to the heuristic mode of information processing, peripheral dynamics and cognitive shortcuts provided by the government and trusted parties affect citizens' voting behavior in direct-democratic settings.

In our case study, the retrospective evaluation of the economic situation strongly influenced respondents' vote choices. The predictor Evaluation Economy, which 
increases as the respondent's evaluation of the economy gets worse, has a negative and statistically significant effect on the probability of voting Yes, and a positive and statistically significant effect on the probability of voting No. In other words, a negative evaluation of the economy was able to both containing the likelihood of voting Yes and fostering the likelihood of voting No. Thus, Hypothesis 2 is confirmed.

Despite this, the heuristic offered by the Renzi cabinet had an impact on the Yes vote only. Coherently with our third hypothesis, the better is respondent's evaluation of the Renzi cabinet, the more he/she is likely to vote Yes. However, as for the predictor Content Evaluation, this mechanism does not explain the choice to vote No.

Partisan attachments play a key role in orienting respondents' voting behavior. All the indicators related to respondents' propensity to vote for a given party (i.e. PTV PD, PTV FI, PTV M5S), except for PTV LN, reach statistical significance in the expected directions. The more a respondent is ready to vote for PD in the next future, the more (the less) he/she will be likely to vote Yes (No) in the constitutional referendum. Conversely, respondents closer to FI and M5S parties, standing on the No-side, are less likely to vote Yes and more likely to vote No. Thus, despite with the exception of LN, Hypothesis 4 is confirmed.

Lastly, at the first nest level, concerning the choice whether to abstain or to take part in the referendum, the negative coefficient on the predictor Political Involvement indicates that individuals are less likely to abstain for increasing values of political participation and activism. Instead, the categorical control variable Labor Market Status suggests that individuals belonging to the 'blue collar' category have a higher propensity to abstain than individuals working as 'employee, executive, professor, and teacher'.

So far, our results propose that the systematic mode of information processing explains the Yes vote fairly. However, being faced with a complex reform package, respondents also employed heuristics and peripheral reasoning reasonably in order to decide how to cast their ballots.

In what follows, we develop an exploratory analysis to understand whether such peripheral dynamics also had conditioning effects on the impact of the predictor Content Evaluation on respondents' voting behavior as well. For instance, our results highlight the key role played by economic voting. However, was a negative evaluation of the economy (heuristic mode) able to nullify the effect of a positive evaluation of the constitutional reform (systematic mode)? Furthermore, did respondents conform to the views of their trusted parties (heuristic mode) even at the cost of neglecting their own opinions on the reform package (systematic mode)? These questions can be answered by estimating the effect of the predictor Content Evaluation on the probability of Yes vote conditional on peripheral dynamics (i.e. Evaluation Economy, Evaluation Renzi Cabinet and PTV for the four major Italian parties). Appendix Table A3 displays the model specifications. Here we discuss the main findings.

Figure 2 shows that only partisan attachments are able to condition the effect of a positive evaluation of the constitutional reform in a significant and consistent way (Brambor et al., 2006). Specifically, as the propensity to vote for FI and M5S increases, the positive effects of the predictor Content Evaluation on the probability 

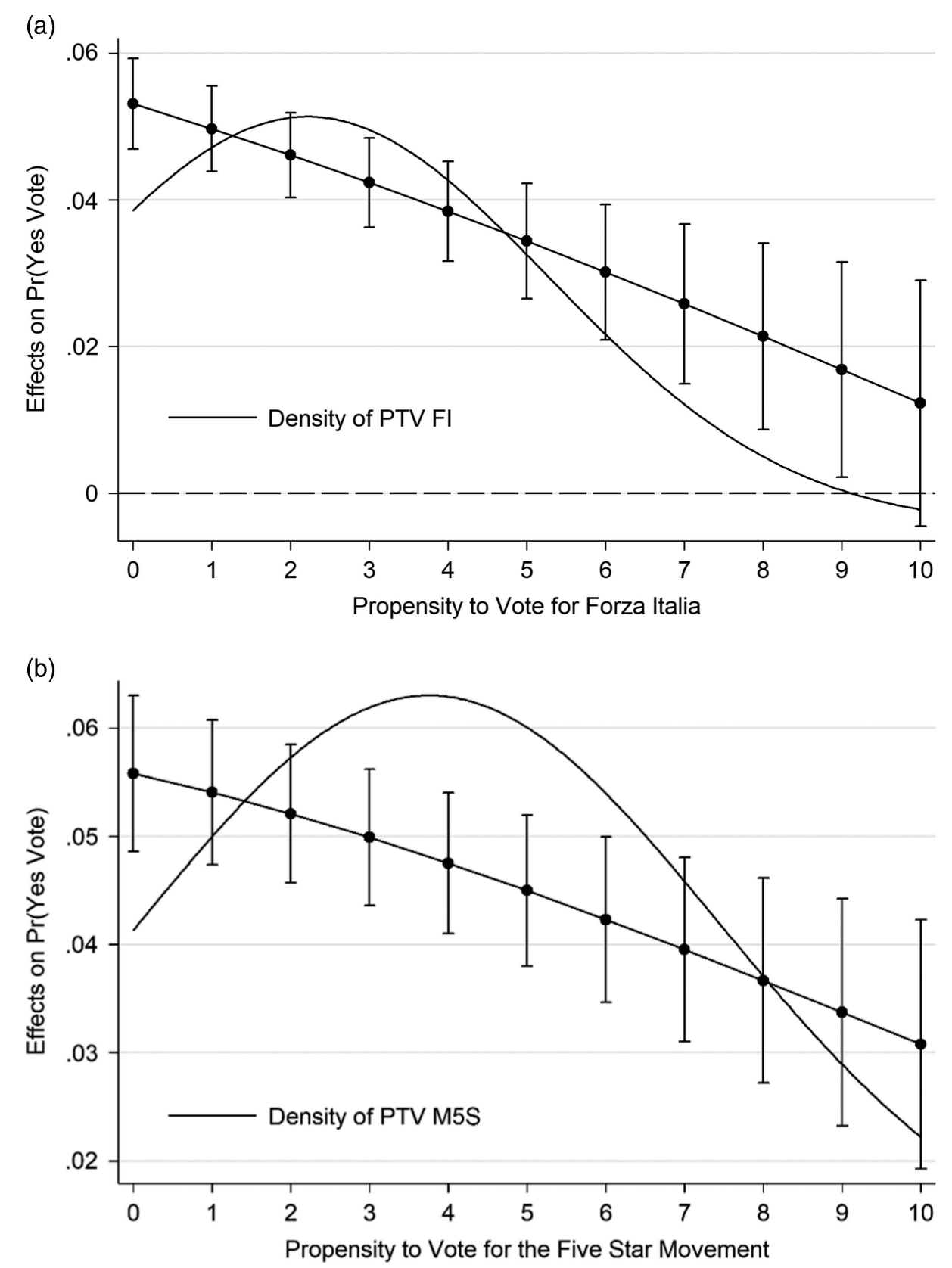

Figure 2 Effects of content evaluation on Yes vote conditional on partisan attachments to Forza Italia (a) and the Five Star Movement (b).

of Yes vote decreases. Thus, partisan attachments not only affected voting choices by their own, but they also diminished the positive effect on Yes vote given by respondent's agreement with the content of the reform.

\section{Conclusions}

In the 2016 constitutional referendum, voters decided how to cast their ballots following both a systematic mode of information processing and cognitive shortcuts. 
According to our results, respondents' assessment of the content of the reform is a key predictor of voting Yes. Notably, the systematic mode of information processing keeps its relevance even when the peripheral dynamics (i.e. the evaluation of the state of the economy, the popularity of the Renzi government and partisan attachments) are controlled for, highlighting that at the very least Yes voters were largely driven by their personal positive evaluation of the reform.

Thus, good news for those who maintain that citizens take part in referendums to express their sincere opinions on the issues at stake and that referendums are fundamental democratic instruments as, in case of success, they guarantee popular legitimacy to radical policy changes (e.g. LeDuc, 2003; Qvortrup, 2005).

However, our results also highlight the effect on vote choices played by three contextual dynamics, namely the retrospective evaluation of the economic situation, respondents' evaluation of the Renzi cabinet and partisan attachments.

A negative evaluation of the state of the economy is a crucial factor in explaining voting behavior. People having a negative judgment of the economic situation seem more prone to vote No, and conversely less inclined to vote Yes. This result points out how punishment strategies motivated by the economic downturn were at play and strongly oriented the choices of No voters.

At the same time, individuals with a positive judgment of the Renzi cabinet were more prone to vote Yes. The key role played by the evaluation of Renzi and his cabinet in shaping vote choices is also underlined by Bellucci et al. (2017) and Colombo et al. (2017).

Similarly, individuals that declared a high propensity to vote for PD were more likely to vote Yes, and less prone to vote No than the supporters of the other parties. Thus, those who strongly supported the PD followed former PM Renzi's position on the referendum.

However - a factor apparently underestimated by PM Renzi - citizens who declared to be ready to vote for FI and M5S have been significantly oriented by their partisan attachments, being more prone to vote No and less inclined to vote Yes.

Moreover, as our exploratory analysis on the conditioning effects of peripheral dynamics shows, not only did partisan attachments affect voting choices, but they also diminished the positive effect on Yes vote given by respondent's agreement with the content of the reform. Quite interestingly, among partisan attachments, the one that seems unable to boost the positive effect of the predictor Content Evaluation on the probability to vote Yes is the propensity to vote for PD. In fact, the most engaged party on the Yes-side initially suffered from an internal division. The referendum activated a well-established and never-faded intra-party cleavage between the mainstream faction led by Renzi and the leftist factions, the first claiming a stronger role for the executive branch and a majoritarian electoral system, the latter supporting a parliamentary regime and a proportional electoral system (Fasano et al., 2017). This intra-party heterogeneity was fixed just 1 month before the referendum thanks to an agreement on the electoral law and is likely to have disoriented PD voters. 
Thus, the proponents of the heuristic mode of information processing in direct democratic settings (e.g. Lodge and Taber, 2013; Taber and Young, 2013) can breathe a sigh of relief: punishment strategies and partisan attachments played a considerable role in the 2016 constitutional referendum.

At this referendum, the Yes-side collected about 13,500,000 (about 41\%) votes. Despite successful in mobilizing its electorate (i.e. PD collected about 8,700,000 votes at the 2013 Italian national elections, about 11,200,000 votes at the 2014 European Parliament elections), PD was largely defeated. Thus, the crucial strategic mistake was that the PD was the only party on the Yes-side (with the negligible contribution of minor NCD party).

The results suggest that Renzi's attempt to use his image and the performance of his cabinet to convince people to vote in favor of the reform has a positive impact on Yes vote. However, this positive impact turned out to be lower than what he could possibly expect.

In the light of referendum results, it is also plausible that Renzi overestimated the initial appreciation of the content of the constitutional reform. This argument is consistent with the study by Conti et al. (2017).

Ultimately, it is possible to claim that Renzi's choice to infringe the so-called Nazareno Pact with FI in order to elect President Mattarella is one of the factors that determined the failure of the 2016 referendum, as it undermined the electoral bases on the Yes-front. In fact, partisan attachments to FI have both a direct and a conditioning negative effect on Yes vote.

Was Mattarella worth the trouble? Our question sounds provocative, but it seems hard to ignore that the infringement of the Nazareno Pact paved the way for the failure of the 2016 constitutional referendum, thus seriously postponing a root and branch overhaul of the constitution once again.

\section{Acknowledgments}

The authors thank David Mellor for helping us in pre-registering our research design on the Open Science Framework website. Moreover, we are grateful to Irene Vanini for proofreading the most intricate paragraphs. Finally, we sincerely thank the two anonymous reviewers: meeting their comments has been hard, but they highly improved the quality of the paper.

\section{Financial Support}

The research received no grants from public, commercial or non-profit funding agency.

\section{Conflicts of Interest}

No conflicts of interest.

\section{Data}

The replication data set is available at http://thedata.harvard.edu/dvn/dv/ipsr-risp 


\section{References}

Bellucci, P., A.D. Angelis and D. Garzia (2017), 'When personalization meets direct democracy. An analysis of the determinants of voting in the Italian Constitutional referendum, 2016'. Paper presented at the ITANES Workshop 'Referendum Costituzionale 2016: Elettori, Partiti e Media nella Seconda Repubblica', February 9-10, Rome.

Borges, W. and H. Clarke (2008), 'Cues in context: analyzing the heuristics of referendum voting with an internet survey experiment', Journal of Elections, Public Opinion and Parties 18(4): 433-448.

Born, R. (1990), 'Surge and decline, negative voting, and the midterm loss phenomenon: a simultaneous choice analysis', American Journal of Political Science 34(3): 615-645.

Boudreau, C. and S.A. MacKenzie (2014), 'Informing the electorate? How party cues and policy information affect public opinion about initiatives', American Journal of Political Science 58: 48-62.

Brambor, T., W.R. Clark and M. Golder (2006), 'Understanding interaction models: improving empirical analyses', Political Analysis 14(1): 63-82.

Bull, M.J. and J.L. Newell (2009), 'Still the anomalous democracy? Politics and institutions in Italy', Government and Opposition 44(1): 42-67.

Camatarri, S. and P. Segatti (2017), 'Le condizioni che avrebbero consentito la vittoria del "sì”'. Il Mulino. Retrieved 4 December 2017 from www.rivistailmulino.it/news/newsitem/index/Item/News:NEWS_ ITEM:3764

Clarke, H., A. Kornberg and M.C. Stewart (2004), 'Referendum voting as political choice: the case of Quebec', British Journal of Political Science 34(2): 345-355.

Clarke, H.D., D. Sanders, M.C. Stewart and P. Whiteley (2013), 'Leader heuristics, political knowledge and voting in Britain's AV referendum', Electoral Studies 32(2): 224-235.

Colombo, C. (2016), 'Justification and citizen competence in direct democracy: a multilevel analysis', British Journal of Political Science, (first published online, 10 May).

Colombo, C., A. de Angelis and D. Morisi (2016), 'New survey evidence: Renzi's support is damaging the chances of a Yes vote in Italy's referendum', EUROPP - European Politics and Policy. Retrieved 26 January 2017 from http://bit.ly/2fJmbaU

Colombo, C., A. De Angelis, H. Kriesi and D. Morisi (2017), 'Demanding choices or easy shortcuts? A study on the 2016 Italian constitutional referendum'. Paper presented at the ITANES Workshop 'Referendum Costituzionale 2016: Elettori, Partiti e Media nella Seconda Repubblica', February 9-10, Rome.

Colombo, C. and H. Kriesi (2016), 'Party, policy-or both? Partisan-biased processing of policy arguments in direct democracy', Journal of Elections, Public Opinion and Parties 27(3): 1-19.

Conti, N., F. Olmastroni and G. Passarelli (2017), 'The Italian Constitutional Referendum. A vote against what?'. Paper presented at the ITANES Workshop 'Referendum Costituzionale 2016: Elettori, Partiti e Media nella Seconda Repubblica', February 9-10, Rome.

De Angelis, A., D. Morisi and C. Colombo (2017), 'Taking cues from the government: Heuristic versus Systematic Processing in a Consitutional Referendum'. Paper presented at the European Political Science Association's 2017 Conference, June 22-24, Milan.

de Vreese, C.H. (2006), 'Political parties in dire straits? Consequences of national referendums for political parties', Party Politics 12(5): 581-598.

Fasano, L.M., P. Natale and N.M. Diodati (2017), 'PD: un partito in cerca di identità e collocazione politica. Implicazioni strategiche per la competizione partitica'. Paper presented at the ITANES Workshop 'Referendum Costituzionale 2016: Elettori, Partiti e Media nella Seconda Repubblica', February 9-10, Rome.

Ferrera, M. and E. Gualmini (2004), Rescued by Europe? Social and Labor Market Reforms in Italy From Maastricht to Berlusconi, Amsterdam: Amsterdam University Press.

Fiorina, M.P. (1981), Retrospective Voting in American National Elections, New Haven: Yale University Press.

Gallagher, M. (1995), 'Conclusions', in M. Gallagher and P.V. Uleri (eds), The Referendum Experience in Europe, London: Macmillan, pp. 226-252.

Gallagher, M. (2015), 'Elezioni e referendum', in D. Caramani (ed.), Manuale di Scienza Politica Handbook of Political Science, Milano: Egea, pp. 261-297. 
Hensher, D.A., J.M. Rose and W.H. Greene (2005), Applied choice Analysis. A Primer, Cambridge: Cambridge university Press.

Hobolt, S.B. (2006), 'How parties affect vote choice in European integration referendums', Party Politics 12(5): 623-647.

Hobolt, S.B. (2007), 'Taking cues on Europe? Voter competence and party endorsements in referendums on European integration', European Journal of Political Research 46: 151-182.

Hobolt, S.B. (2009), Europe in Question: Referendums on European Integration, Oxford: Oxford University Press.

Hobolt, S.B. (2016), 'The Brexit vote: a divided nation, a divided continent', Journal of European Public Policy 23(9): 1259-1277.

Keating, M. and A. Wilson (2010), 'Federalism and decentralisation in Italy.' PSA Conference Paper. Retrieved 2 March 2017 from http://scienzepolitiche.unical.it

Kahneman, D. (2011), Thinking, Fast and Slow, London: Allen Lane.

Kriesi, H. (2005), Direct Democratic Choice: The Swiss Experience, Lanham, MD: Lexington Books.

LeDuc, L. (2003), The Politics of Direct Democracy: Referendums in Global Perspective, Peterborough: Broadview Press.

Lewis-Beck, M.S. and M. Stegmaier (2007), 'Economic models of voting', in R.J. Dalton and H.-D. Klingemann (eds), The Oxford Handbook of Political Behavior, Oxford: Oxford University Press. Retrieved 4 December 2017 from http://www.oxfordhandbooks.com/view/10.1093/oxfordhb/9780199270125. 001.0001/oxfordhb-9780199270125-e-027.

Lijphart, A. (2012), Patterns of Democracy. Government Forms and Performance in Thirty-Six Countries, 2nd edn, New Haven \& London: Yale University Press.

Lodge, M. and C.S. Taber (2013), The Rationalizing Voter, Cambridge: Cambridge University Press.

Luce, R.D. (1959), Choice Behavior. A Theoretical Analysis, New York: Wiley.

Lupia, A. (1994), 'Shortcuts versus encyclopedias: information and voting behavior in California insurance reform elections', American Political Science Review 88(1): 63-76.

Lupia, A. and M.D. McCubbins (1998), The Democratic Dilemma: Can Citizens Learn What They Need To Know?, New York: Cambridge University Press.

Lupia, A., M. McCubbins and S. Popkin (2000), Elements of Reason: Cognition, Choice, and the Bounds of Rationality, New York: Cambridge University Press.

Lupia, A. and J.G. Matsusaka (2004), 'Direct democracy: new approaches to old questions', Annual Review of Political Science 7: 463-482.

Manski, C.F. (1977), 'The structure of random utility models', Theory and Decisions 8: 229-254.

McFadden, D. (1978), 'Modelling the choice of residential location', in K. Anders, L. Lundqvist, F. Snickars and J.W. Weibull (eds), Spatial Interaction Theory and Planning Models, Amsterdam: North-Holland, pp. $75-96$.

Neijens, P. and P. van Praag (2006), 'The dynamics of opinion formation in local popular referendums: why the Dutch always say no', International Journal of Public Opinion Research 18(4): 445-462.

Qvortrup, M. (2005), A Comparative Study of Referendums: Government by the People, Manchester: Manchester University Press.

Reif, K. and H. Schmitt (1980), 'Nine second-order national elections: a conceptual framework for the analysis of European election results', European Journal of Political Research 8(1): 3-44.

Sentimeter (2015), 'Boom di consensi per Mattarella. Ma il $42 \%$ ora si aspetta un freno alle riforme'. http:// sentimeter.corriere.it/page/3/ (consulted on 5 February 2017).

Slothuus, R. and C.H. de Vreese (2010), 'Political parties, motivated reasoning, and issue framing effects', The Journal of Politics 72: 630-645.

Steenbergen, M.R. (2008), 'Discrete choice models for political analysis'. Advanced Political Methodology Lecture Notes/Skript. Retrieved 4 December 2017 from https://politique.cuso.ch/fileadmin/politique/ document/Steenbergen-2008.pdf

Stokes, D.E. (1963), 'Spatial models of party competition', American Political Science Review 57(2): 368-377.

Taber, C.S. and E. Young (2013), 'Political information processing', in L. Huddy, D.O. Sears and J.S. Levy (eds), The Oxford Handbook of Political Psychology, 2nd edn, Oxford: Oxford University Press. 
Thurner, P.W. and A. Eymann (2000), 'Policy-specific alienation and indifference in the calculus of voting: a simultaneous model of party choice and abstention', Public Choice 102: 51-77.

Train, K.E. (2007), Discrete Choice Models with Simulation, New York: Cambridge University Press.

Tsebelis, G. (2002), Veto Players: Foundations of Institutional Analysis, Princeton, NJ: Princeton University Press. Tsebelis, G. (2017), 'Compromesso Astorico: the role of the Senate after the Italian constitutional reform', Italian Political Science Review 47(1): 87-104.

\section{Appendix}

\section{Table A1. Variables' description}

\begin{tabular}{|c|c|}
\hline Name & Sources and description \\
\hline Voting behavior & $\begin{array}{l}\text { Multi-categorical dependent variable given by ITANES’s item D28 } \\
\text { (Post-referendum wave) }\end{array}$ \\
\hline Content evaluation & $\begin{array}{l}\text { Additive index given by ITANES's items S26, S33.1, S33.2, S33.3, S33.4 } \\
\text { (Pre-referendum wave) and D27.1 (Pre-referendum wave) }\end{array}$ \\
\hline Evaluation economy & ITANES’s variable S18 (Pre-referendum wave), rescaled \\
\hline $\begin{array}{l}\text { Evaluation Renzi } \\
\text { Cabinet }\end{array}$ & ITANES's variable S20 (Pre-referendum wave) \\
\hline Propensity to vote PD & ITANES's variable D35.1 (Post-referendum wave) \\
\hline Propensity to vote FI & ITANES's variable D35.2 (Post-referendum wave) \\
\hline Propensity to vote M5S & ITANES's variable D35.4 (Post-referendum wave) \\
\hline Propensity to vote $\mathrm{LN}$ & ITANES's variable D35.5 (Post-referendum wave) \\
\hline Political involvement & $\begin{array}{l}\text { Additive index given by ITANES's items D16, D17, D18.1, D18.2, D18.7 } \\
\text { (Post-referendum wave) }\end{array}$ \\
\hline Education & $\begin{array}{l}\text { Ordinal variable derived from ITANES's item S10 (Pre-referendum wave). } \\
\text { It is equal to: } \\
\text { 1. No educational degree or elementary degree } \\
\text { 2. Junior high school degree } \\
\text { 3. High school degree } \\
\text { 4. University degree or higher }\end{array}$ \\
\hline Labor market status & $\begin{array}{l}\text { Categorical variable derived from ITANES's items S11, S12, and S14 } \\
\text { (Pre-referendum wave). It is equal to: } \\
\text { Employer, freelance, or director } \\
\text { Self-employed, shop keeper, sales agent, artisan } \\
\text { Employee, executive, professor, teacher (reference category) } \\
\text { Blue collar } \\
\text { Unemployed } \\
\text { Student } \\
\text { Housewife/maker } \\
\text { Retired person } \\
\text { Other }\end{array}$ \\
\hline Age & $\begin{array}{l}\text { Ordinal variable derived from ITANES's item S2 (Pre-referendum wave). } \\
\text { It is equal to: } \\
\text { 1. } 18-34 \text { years old; } \\
\text { 2. } 35-54 \text { years old; } \\
\text { 3. } 55 \text { years old or more }\end{array}$ \\
\hline Female & Dummy variable derived from ITANES's item S1 (Pre-referendum wave) \\
\hline
\end{tabular}


Table A2. Descriptive statistics

\begin{tabular}{|c|c|c|c|c|}
\hline Variable & Mean & Std. dev. & Min. & Max. \\
\hline Voting behavior (categorical) & 1.659 & 0.904 & 1 & 4 \\
\hline Content evaluation & 5.137 & 2.471 & 0 & 10 \\
\hline Evaluation economy & 6.06 & 2.204 & 0 & 10 \\
\hline Evaluation Renzi Cabinet & 3.825 & 2.765 & 0 & 10 \\
\hline PTV PD & 3.409 & 3.412 & 0 & 10 \\
\hline PTV FI & 2.158 & 3.044 & 0 & 10 \\
\hline PTV M5S & 3.660 & 3.673 & 0 & 10 \\
\hline PTV LN & 2.465 & 3.396 & 0 & 10 \\
\hline Political involvement & 3.195 & 0.847 & 0 & 5 \\
\hline Education & 3.165 & 0.686 & 1 & 4 \\
\hline Labor market status (categorical) & 4.562 & 2.368 & 1 & 9 \\
\hline Age & 2.128 & 0.785 & 1 & 3 \\
\hline Female & 0.479 & 0.499 & 0 & 1 \\
\hline
\end{tabular}

Table A3. Determinants of Yes vote - conditional effects

\begin{tabular}{|c|c|c|c|c|}
\hline & M0 & M1 & M2 & \\
\hline Content evaluation & $0.397(0.034) * * *$ & $0.353(0.113)^{* *}$ & $0.411(0.065)^{* * *}$ & \\
\hline Evaluation economy & $-0.005(0.039)$ & $-0.049(0.122)$ & $-0.005(0.039)$ & \\
\hline $\begin{array}{l}\text { Content evaluation } \times \text { evaluation } \\
\text { economy }\end{array}$ & & $0.008(0.018)$ & & \\
\hline Evaluation Renzi Cabinet & $0.295(0.037) * * *$ & $0.295(0.037) * * *$ & $0.314(0.088) * * *$ & \\
\hline $\begin{array}{l}\text { Content evaluation } \times \text { evaluation } \\
\text { Renzi Cabinet }\end{array}$ & & & $-0.003(0.013)$ & \\
\hline PTV PD & $0.195(0.023) * * *$ & $0.196(0.023) * * *$ & $0.195(0.023) * * *$ & \\
\hline PTV FI & $-0.114(0.029) * * *$ & $-0.113(0.029)^{* * *}$ & $-0.114(0.029) * * *$ & \\
\hline PTV M5S & $-0.215(0.020) * * *$ & $-0.215(0.020)^{* * *}$ & $-0.214(0.020) * * *$ & \\
\hline PTV LN & $-0.076(0.027)^{* *}$ & $-0.076(0.027)^{* *}$ & $-0.076(0.027)^{*}$ & \\
\hline Control variables & Yes & Yes & Yes & \\
\hline Constant & Yes & Yes & Yes & \\
\hline$N$ & 2477 & 2477 & 2477 & \\
\hline \multirow[t]{2}{*}{ Pseudo $R^{2}$} & 0.47 & 0.47 & 0.47 & \\
\hline & M3 & M4 & M5 & M6 \\
\hline Content evaluation & $0.426(0.048) * * *$ & $0.479(0.040)^{* * *}$ & $0.445(0.042)^{* * *}$ & $0.433(0.037)^{* * * *}$ \\
\hline Evaluation economy & $-0.007(0.039)$ & $-0.007(0.039)$ & $-0.003(0.039)$ & $-0.004(0.039)$ \\
\hline Evaluation Renzi Cabinet & $0.297(0.037) * * *$ & $0.299(0.037) * * *$ & $0.298(0.037)^{* * *}$ & $0.299(0.037)^{* * * *}$ \\
\hline PTV PD & $0.244(0.063) * * *$ & $0.199(0.023) * * *$ & $0.198(0.023) * * *$ & $0.196(0.023)^{* * * *}$ \\
\hline Content evaluation $\times$ PTV PD & $-0.008(0.009)$ & & & \\
\hline PTV FI & $-0.114(0.029) * * *$ & $0.116(0.065) *$ & $-0.114(0.029) * * *$ & $-0.112(0.029) * * *$ \\
\hline Content evaluation $\times$ PTV FI & & $-0.038(0.01)^{* * *}$ & & \\
\hline PTV M5S & $-0.214(0.020) * * *$ & $-0.213(0.020)^{* * *}$ & $-0.122(0.056)^{* *}$ & $-0.214(0.020) * * *$ \\
\hline Content evaluation $\times$ PTV M5S & & & $-0.016(0.009)^{*}$ & \\
\hline PTV LN & $-0.075(0.027)^{* *}$ & $-0.074(0.026)^{* * *}$ & $-0.074(0.027)^{*}$ & $0.027(0.059)$ \\
\hline Content evaluation $\times$ PTV LN & & & & $-0.017(0.009)^{*}$ \\
\hline Control variables & Yes & Yes & Yes & Yes \\
\hline Constant & Yes & Yes & Yes & Yes \\
\hline$N$ & 2477 & 2477 & 2477 & 2477 \\
\hline Pseudo $R^{2}$ & 0.47 & 0.48 & 0.47 & 0.47 \\
\hline
\end{tabular}

Logit models. The outcome variable is equal to 1 if respondent took part in the 2016 constitutional referendum and voted Yes, 0 otherwise. Robust SE in parentheses.

$* * * P<0.01, * P<0.05, * P<0.1$. 